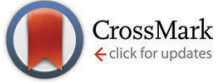

Cite this: Phys. Chem. Chem. Phys., 2015, 17, 12080

Received 26th December 2014, Accepted 9th April 2015

DOI: $10.1039 / \mathrm{c} 4 \mathrm{cp} 06076 \mathrm{~h}$

www.rsc.org/pccp

\title{
Electrodeposition of germanium at elevated temperatures and pressures from ionic liquids $\uparrow$
}

\author{
Minxian Wu, ${ }^{a}$ Gijs Vanhoutte, ${ }^{a}$ Neil R. Brooks, ${ }^{b}$ Koen Binnemans ${ }^{b}$ and \\ Jan Fransaer*a
}

\begin{abstract}
The electrodeposition of germanium at elevated temperatures up to $180{ }^{\circ} \mathrm{C}$ and pressures was studied from the ionic liquids 1-butyl-1-methylpyrrolidinium dicyanamide and 1-butyl-1-methylpyrrolidinium bis(trifluoromethylsulfonyl)imide containing $\left[\mathrm{GeCl}_{4}(\mathrm{Bulm})_{2}\right]$ (where Bulm = 1-butylimidazole) or $\mathrm{GeCl}_{4}$. Cyclic voltammetry (CV), electrochemical quartz crystal microbalance (EQCM), rotating ring-disk electrode (RRDE), scanning electron microscope (SEM), X-ray diffraction (XRD), transmission electron microscopy (TEM), electron backscatter diffraction (EBSD) and Auger electron spectroscopy (AES) were used to investigate the electrochemical behavior and the properties of the electrodeposited germanium. Electrodeposition at elevated temperatures leads to higher deposition rates due to: (1) increase in the diffusion rate of the electroactive germanium compounds; (2) faster electrochemical kinetics in the electrolyte; and (3) higher electrical conductivity of the electrodeposited germanium film. Moreover, the morphology of the germanium film is also of a better quality at higher electrodeposition temperatures due to an increase in adatom mobility.
\end{abstract}

\section{Introduction}

The electrodeposition of germanium thin films is receiving a lot of attention from the scientific community, thanks to the importance of germanium in semiconductor applications. ${ }^{1-4}$ Thin films of germanium can be fabricated from various solutions using electrodeposition. Due to the low overpotential for hydrogen evolution on germanium electrodes, only ultrathin germanium layers could be obtained from aqueous solutions. ${ }^{5-7}$ Grey shiny germanium films were electrodeposited from organic solvents, e.g. ethylene glycol, propylene glycol, etc. ${ }^{8-10}$ However, the current efficiency for electrodeposition from protic organic electrolytes such as ethylene glycol and propylene glycol is very low due to formation of hydrogen gas. To avoid hydrogen evolution, electrolytes based on supercritical fluids or ionic liquids are gaining more and more interest. ${ }^{3,11}$

Ionic liquids are solvents that consist entirely of ions. They have a wide electrochemical window and an intrinsic ionic

\footnotetext{
${ }^{a}$ Department of Materials Engineering, KU Leuven, Kasteelpark Arenberg 44 - bus 2450, B-3001 Leuven, Belgium. E-mail: jan.fransaer@mtm.kuleuven.be; Fax: +32 1632 19 91; Tel: +3216321260

${ }^{b}$ Department of Chemistry, KU Leuven, Celestijnenlaan 200F - bus 2404, B-3001 Leuven, Belgium

$\dagger$ Electronic supplementary information (ESI) available: SEM images of the germanium film electrodeposited from [BMP][DCA] and [BMP][Tf $\left.{ }_{2} \mathrm{~N}\right]$; a photo-

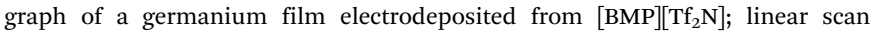
voltammograms of $0.5 \mathrm{M} \mathrm{GeCl}_{4}$ in $[\mathrm{BMP}]\left[\mathrm{Tf}_{2} \mathrm{~N}\right]$; viscosity of $[\mathrm{BMP}]\left[\mathrm{Tf}_{2} \mathrm{~N}\right]$ at different temperatures. See DOI: 10.1039/c4cp06076h
}

conductivity. ${ }^{12,13}$ Using ionic liquids as electrolytes and performing electrodeposition from ionic liquids has been a hot research topic during last decade. Some metals that are impossible to deposit from water due to hydrolysis or due to the fact that hydrogen evolution happens before metal ion reduction can be electrodeposited from ionic liquids because water can be easily removed. ${ }^{14}$ Endres and coworkers first reported on germanium electrodeposition from the ionic liquid 1-butyl-3methylimidazolium hexafluorophosphate using germanium(Iv) halides as germanium source. ${ }^{15-18}$ Germanium nanoclusters were obtained, but carbon, oxygen and halogen impurities were detected in the deposits. Germanium has also been electrodeposited from other ionic liquids, e.g. 1-butyl-3-methylimidazolium bis(trifluoromethylsulfonyl)imide, 1-butyl-1-methylpyrrolidinium bis(trifluoromethylsulfonyl)imide, 1-ethyl-2,3-dimethylimidazolium bis(trifluoromethylsulfonyl)imide. ${ }^{19-21}$ Due to the low boiling point of $\mathrm{GeCl}_{4}\left(86.5{ }^{\circ} \mathrm{C}\right)$, most of the depositions have been carried out at room temperature. Xin et al. performed $\mathrm{Si}_{x} \mathrm{Ge}_{1-x}$ deposition from 1-ethyl-3-methylimidazolium bis(trifluoromethylsulfonyl)imide using $\mathrm{GeCl}_{4}$ and $\mathrm{SiCl}_{4}$ at $90{ }^{\circ} \mathrm{C}$ and found a 2D-ordered $\mathrm{Si}_{x} \mathrm{Ge}_{1-x}$ deposit at $90{ }^{\circ} \mathrm{C}$ instead of the $3 \mathrm{D}$ structure that was formed at room temperature. ${ }^{22}$ The film morphology was improved due to the increase of adatom mobility on the surface at elevated temperatures. ${ }^{23}$ To prevent the evaporation of the electroactive germanium compound, we used a new germanium compound $\left[\mathrm{GeCl}_{4}(\mathrm{BuIm})_{2}\right]$ (where BuIm = 1-butylimidazole), which is much less volatile than $\mathrm{GeCl}_{4}$, and successfully electrodeposited porous germanium films from a mixture 
of 1-butyl-1-methylpyrrolidinium dicyanamide and 1-butyl-1methylpyrrolidinium chloride at $100{ }^{\circ} \mathrm{C} .{ }^{24}$ The deposition rate at $100{ }^{\circ} \mathrm{C}$ was much higher than at room temperature. Because at elevated temperatures, both the diffusion rate of germanium ions and electrochemical kinetics are increased. Also, the electrical conductivity $(\sigma)$ of electrodeposited germanium film also increased at higher temperatures as $\sigma \propto \exp \left(-E_{\mathrm{g}} / 2 k_{\mathrm{B}} T\right)$, where $E_{\mathrm{g}}$ is the band gap of the material, $\mathrm{k}_{\mathrm{B}}$ is the Boltzmann constant, and $T$ is the absolute temperature. ${ }^{25}$

This paper is about the electrodeposition of germanium at elevated temperatures up to $120{ }^{\circ} \mathrm{C}$ from 1-butyl-1-methylpyrrolidinium dicyanamide and up to $180{ }^{\circ} \mathrm{C}$ from 1-butyl-1methylpyrrolidinium bis(trifluoromethylsulfonyl)imide. To prevent the evaporation of $\left[\mathrm{GeCl}_{4}(\mathrm{BuIm})_{2}\right]$ and $\mathrm{GeCl}_{4}$, a high pressure electrochemical cell was built. At temperatures higher than $150{ }^{\circ} \mathrm{C}$, dense shiny germanium films could be electrodeposited and high deposition rates could be obtained.

\section{Experimental}

The ionic liquids 1-butyl-1-methylpyrrolidinium bis(trifluoromethylsulfonyl)imide [BMP] $\left[\mathrm{Tf}_{2} \mathrm{~N}\right]($ IoLiTec, $>98 \%$ ) and 1-butyl-1methylpyrrolidinium dicyanamide [BMP][DCA] (IoLiTec, >98\%) were thoroughly dried in a vacuum of $0.6 \mathrm{mbar}$ at $120{ }^{\circ} \mathrm{C}$ for at least $8 \mathrm{~h}$. $\mathrm{GeCl}_{4}$ (Umicore, Olen, Belgium, 99.99\%) was used as received. $\left[\mathrm{GeCl}_{4}(\mathrm{BuIm})_{2}\right]$ was synthesized according to a literature procedure. $^{24}$

The electrolyte solutions were prepared in an argon-filled glove box (oxygen and water contents were below $1 \mathrm{ppm}$ ), and then the electrolytes were transferred into a closed pressure cell. The schematic drawing of the pressure electrochemical cell is shown in Fig. 1. It was a cylindrical glass cell with a screw cap. The electrochemical experiments were performed outside the glove box and the closed cell was entirely immersed in a hot silicon oil bath. All the electrochemical experiments were carried out in a three-electrode system. The counter electrode was a p-type germanium wafer and a platinum wire was used as a pseudo-reference electrode. The working electrode used for

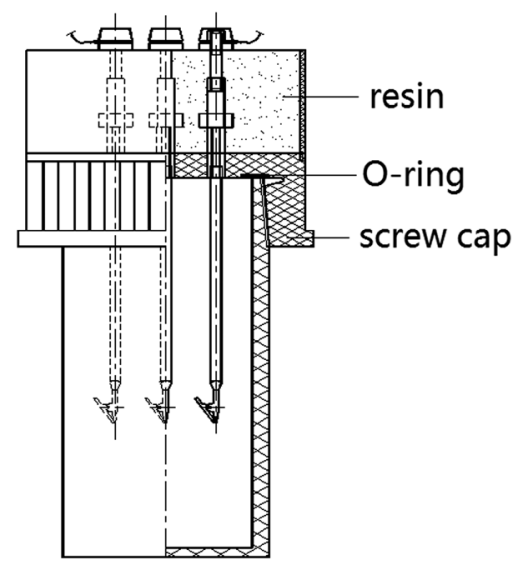

Fig. 1 Schematic drawing of the electrochemcial cell used for electrochemical experiments at elevated temperatures. cyclic voltammetry and for linear scan voltammetry experiments was a polished platinum disk $(\phi=1 \mathrm{~mm})$ embedded in EpoFix ${ }^{\circledR}$ resin. In rotating ring-disk electrode experiments, a platinum/platinum rotating ring-disk electrode (Pine Research Instrumentation, E7R8 Series) was used as working electrode. The dimensions of the ring and disk electrodes were provided by the supplier. The disk has a diameter of $4.57 \mathrm{~mm}\left(2 r_{1}\right)$, and the inside and outside diameters of the ring are $4.93 \mathrm{~mm}\left(2 r_{2}\right)$ and $5.38 \mathrm{~mm}\left(2 r_{3}\right)$, respectively. Platinum-coated silicon wafers (silicon covered with $500 \mathrm{~nm}$ of silica, $10 \mathrm{~nm}$ of titanium and $100 \mathrm{~nm}$ of platinum) or n-type germanium wafers (Umicore, Cz88 742) were used as working electrode for germanium deposition. Before electrodeposition, all the substrates were rinsed with deionized water and absolute ethanol and finally dried in a stream of hot air. An EG \& G 273 potentiostat or an Autolab $302 \mathrm{~N}$ was used for electrochemical experiments.

The electrochemistry of germanium deposition in $[\mathrm{BMP}]\left[\mathrm{Tf}_{2} \mathrm{~N}\right]$ was studied by electrochemical quartz crystal microbalance (EQCM, Maxtek RS232/IEEE488). The mass change per unit area $(\Delta m)$ on a platinum-coated $5 \mathrm{MHz}$ quartz crystal was determined by the Sauerbrey equation:

$$
\Delta f=-C_{\mathrm{f}} \Delta m
$$

where $\Delta f$ is the frequency change; and $C_{\mathrm{f}}$ is the sensitivity factor of the crystal, which was calibrated as $6523 \mathrm{~Hz} \mathrm{~g}^{-1} \mathrm{~m}^{2}$ in $[\mathrm{BMP}]\left[\mathrm{Tf}_{2} \mathrm{~N}\right]$ solutions. The calibration was done according to the method described by Gabrielli et al. ${ }^{26}$ A solution of $50 \mathrm{mM}$ $\left[\mathrm{Ag}(\mathrm{MeCN})_{4}\right]_{2}\left[\mathrm{Ag}\left(\mathrm{Tf}_{2} \mathrm{~N}\right)_{3}\right]$ in $[\mathrm{BMP}]\left[\mathrm{Tf}_{2} \mathrm{~N}\right]$ was used for calibration, and deposition was done at a constant potential. The sensitivity factor was calculated using the Sauerbrey equation by assuming the current efficiency for silver deposition in this solution is $100 \%$. $\left[\mathrm{Ag}(\mathrm{MeCN})_{4}\right]_{2}\left[\mathrm{Ag}\left(\mathrm{Tf}_{2} \mathrm{~N}\right)_{3}\right]$ was chosen because it has higher solubility in $[\mathrm{BMP}]\left[\mathrm{Tf}_{2} \mathrm{~N}\right]$ than $\mathrm{AgNO}_{3}$. It was prepared according to a literature procedure. ${ }^{27,28}$

The concentration of $[\mathrm{BMP}]\left[\mathrm{Tf}_{2} \mathrm{~N}\right]$ containing $\mathrm{GeCl}_{4}$ was determined using inductively coupled plasma optical emission spectroscopy (ICP-OES, Varian 720-ES apparatus). Because $[\mathrm{BMP}]\left[\mathrm{Tf}_{2} \mathrm{~N}\right]$ is immiscible with water, methanol was added to make the ICP solutions. The morphology and elemental composition of the films were determined by scanning electron microscopy (SEM) and energy-dispersive X-ray spectroscopy (EDX, Philips XL 30 FEG). X-ray diffraction (XRD, Seifert 3003), transmission electron microscopy (TEM, FEI Tecnai G2 F20) and electron backscatter diffraction (EBSD) were used to characterize the crystal structure of the deposits. TEM sample was prepared with focused ion beam (FIB, FEI Helios). EBSD was performed using a TSL-EDAX system on an FEI Nova 600 NanoLab instrument. The cross-sections for EBSD measurement and SEM were prepared using a JEOL cross-section polisher.

Auger electron spectroscopy (AES) was used for analyzing the carbon impurity in the germanium film. The Auger chamber (Thermo Scientific) was under ultrahigh vacuum $\left(8.9 \times 10^{-9}\right.$ Torr) and spectra were measured using a primary electron beam with an energy of $8 \mathrm{keV}$ with a typical current of $10 \mathrm{nA}$ and a Gaussian profile with a radius of about $0.5 \mathrm{~mm}$. Auger electrons were detected with a hemispherical analyzer (Thermo Scientific) in 
an energy range from $100 \mathrm{eV}$ up to $1500 \mathrm{eV}$. Depth profiling was done by sputtering with an argon ion beam for $5 \mathrm{~min}$ between each AES measurement. The sputter beam current was approximately $3 \mu \mathrm{A}$, and the beam size had a Gaussian profile with a diameter of approximately $1 \mathrm{~mm}$ and was scanned over an area of $2 \times 2 \mathrm{~mm}^{2}$. AES spectra was analyzed using Avantage Data System software (Thermo Scientific).

\section{Results and discussion}

\subsection{Electrodeposition of germanium using $\left[\mathrm{GeCl}_{4}(\mathrm{BuIm})_{2}\right]$}

In the authors' previous experiments, uniform and porous germanium films could be electrodeposited from $0.1 \mathrm{M}\left[\mathrm{GeCl}_{4}(\mathrm{BuIm})_{2}\right]$ in $[\mathrm{BMP}][\mathrm{DCA}]$ at room temperature. ${ }^{24}$ The deposition rate was calculated from the mass change on a electrochemical quartz crystal microbalance and it was $0.87 \mu \mathrm{m} \mathrm{h}^{-1}$. Efforts to increase the deposition rate were made by increasing the $\left[\mathrm{GeCl}_{4}(\mathrm{BuIm})_{2}\right]$ concentration to $0.4 \mathrm{M}$ in [BMP][DCA]. Unfortunately, due to the high viscosity of the solution, the deposition rate did not significantly increase. ${ }^{24}$ To increase the deposition rate, a [BMP][DCA] solution containing $0.4 \mathrm{M}\left[\mathrm{GeCl}_{4}(\mathrm{BuIm})_{2}\right]$ was heated to $120{ }^{\circ} \mathrm{C}$. Germanium films were electrodeposited at different potentials. The film deposited at $-1.6 \mathrm{~V}$ (vs. Pt) had an orange color and showed many cracks on the surface (see ESI $\dagger$ ). The EDX spectrum of the deposit showed the film also contains a considerable amount of oxygen. Due to the bad adhesion between the germanium film and platinum substrate, the germanium film pealed off during ultrasonic cleaning. The theoretical deposition rate was calculated from the applied charge based on Faraday's law and it reached $2.0 \mu \mathrm{m} \mathrm{h}^{-1}$. This value is close to the germanium deposition rate reported in propylene glycol containing 5 vol\% $\mathrm{GeCl}_{4}\left(\sim 2.2 \mu \mathrm{m} \mathrm{h}^{-1}\right) .{ }^{10}$ However, due to the polymerization of dicyanamide anions, the solution darkened and became more viscous during the electrodeposition process. Polymerization of [BMP $][\mathrm{DCA}]$ is caused, not only by applied electrical current, but also by the high temperature. ${ }^{29,30}$ Fig. 2 shows the color of pure $[\mathrm{BMP}][\mathrm{DCA}]$ after heating at $140{ }^{\circ} \mathrm{C}$ for different times. The solution turned darker at longer heating times, indicating that the polymerization took place during heating. The discoloration at elevated temperature is similar to the one due to the applied

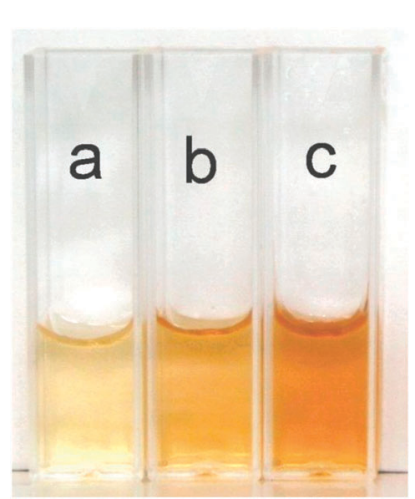

Fig. 2 Color changes of pure [BMP][DCA] after heating at $140{ }^{\circ} \mathrm{C}$ for different times: (a) $0 \mathrm{~h}$, (b) $20 \mathrm{~h}$, and (c) $72 \mathrm{~h}$. electrical charge. ${ }^{24}$ The increase in viscosity due to the polymerization led to a decrease of the deposition rate. Because of the fast polymerization $[\mathrm{DCA}]^{-}$ions, germanium films could not be obtained at temperatures higher than $140{ }^{\circ} \mathrm{C}$ from [BMP][DCA].

\subsection{Electrodeposition of germanium using $\mathrm{GeCl}_{4}$}

$\mathrm{GeCl}_{4}$ has a high solubility in $[\mathrm{BMP}]\left[\mathrm{Tf}_{2} \mathrm{~N}\right]$. A $[\mathrm{BMP}]\left[\mathrm{Tf}_{2} \mathrm{~N}\right]$ solution containing $0.5 \mathrm{M}$ was used for deposition of germanium. However, due to the low boiling temperature of $\mathrm{GeCl}_{4}$ $\left(86.5{ }^{\circ} \mathrm{C}\right)$, the loss of $\mathrm{GeCl}_{4}$ in $[\mathrm{BMP}]\left[\mathrm{Tf}_{2} \mathrm{~N}\right]$ at elevated temperatures is significant. The evaporation of $\mathrm{GeCl}_{4}$ even occurred at room temperature as detected by ICP-OES. After exposing the solution in argon atmosphere for $30 \mathrm{~min}$, the concentration of $\mathrm{GeCl}_{4}$ in $[\mathrm{BMP}]\left[\mathrm{Tf}_{2} \mathrm{~N}\right]$ decreased to $0.37 \mathrm{M}$. The solution was further heated at $150{ }^{\circ} \mathrm{C}$ for one hour, and then no germanium trace was found in the solution, which means all $\mathrm{GeCl}_{4}$ has evaporated. To prevent the loss of germanium, a three-electrode pressure cell which could be totally sealed was designed and used for $\mathrm{GeCl}_{4}$ solutions in $[\mathrm{BMP}]\left[\mathrm{Tf}_{2} \mathrm{~N}\right]$ at higher temperatures (Fig. 1). When the temperature increased, the evaporation of $\mathrm{GeCl}_{4}$ leads to an increase in the pressure above the solution (autogenerated $\mathrm{GeCl}_{4}$ atmosphere), preventing the further loss of $\mathrm{GeCl}_{4}$. The pressure change with temperature can be calculated from the Clapeyron equation:

$$
\ln \left(\frac{P_{2}}{P_{1}}\right)=\frac{\Delta H_{\mathrm{v}}}{\mathrm{R}}\left(\frac{1}{T_{1}}-\frac{1}{T_{2}}\right)
$$

where $P$ is the pressure $(\mathrm{Pa}), \Delta H_{\mathrm{v}}$ is the molar heat of evaporation $\left(\mathrm{J} \mathrm{mol}^{-1}\right), \mathrm{R}$ is the gas constant $\left(8.314 \mathrm{~J} \mathrm{~K}^{-1} \mathrm{~mol}^{-1}\right)$, and $T$ is the temperature (K). The pressure calculated based on eqn (2) at different temperatures is shown in Fig. 3. Laubengayer et al. showed that the actual experimental pressures agreed with the calculated. ${ }^{31}$ At $150{ }^{\circ} \mathrm{C}$, the pressure is expected to increase to about 4 bar.

The viscosity and density of $[\mathrm{BMP}]\left[\mathrm{Tf}_{2} \mathrm{~N}\right]$ change with temperature. The density of $[\mathrm{BMP}]\left[\mathrm{Tf}_{2} \mathrm{~N}\right]$ at different temperatures was described in the literature. ${ }^{32,33}$ The kinematic viscosity $(\nu)$ of pure $[\mathrm{BMP}]\left[\mathrm{Tf}_{2} \mathrm{~N}\right]$ was measured at different temperatures and was converted to dynamic viscosity (Fig. 4). The viscosity

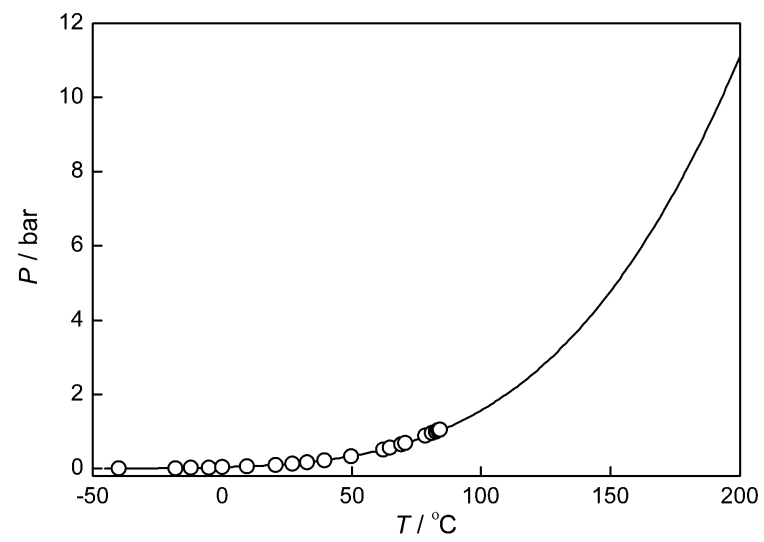

Fig. 3 Vapor pressure of $\mathrm{GeCl}_{4}$ as a function of temperature. The black line was calculated based on eqn (2) and the circles are the experimental data from the literature. ${ }^{31}$ 


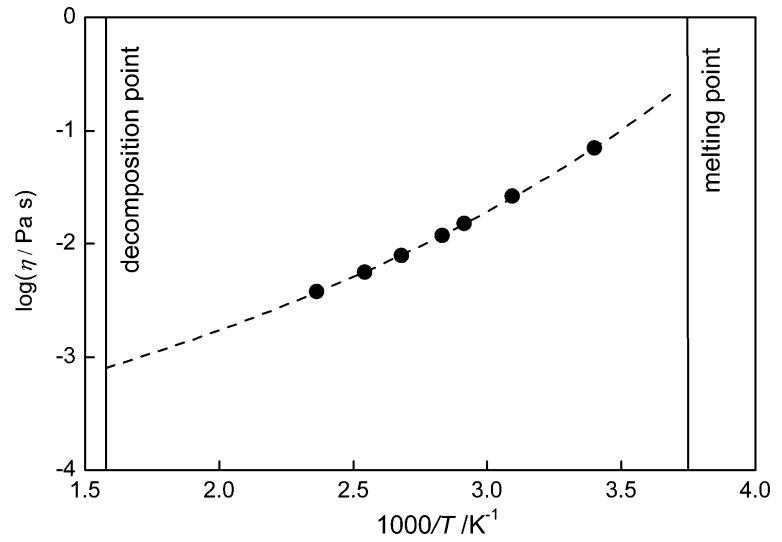

Fig. 4 Tammann-Vogel-Fulcher fitting of viscosity change of ionic liquid $[\mathrm{BMP}]\left[\mathrm{Tf}_{2} \mathrm{~N}\right]$ with temperature.

non-linearly decreases with increasing temperatures. This nonlinear effect can be described by the Tammann-Vogel-Fulcher (TVF) equation:

$$
\log \eta=\log \eta_{0}-B /\left(T-T_{0}\right)
$$

where $\eta$ is the dynamic viscosity (Pa s), $T$ is temperature (K), $\eta_{0}$, $B$ and $T_{0}$ are adjustable parameters. $\eta_{0}$ is the viscosity at infinite temperature, $T_{0}$ is the temperature at which the viscosity become infinite, and parameter $B$ corresponds to the pseudo-activation energy associated with viscous flow. ${ }^{34}$ The best fit for $\eta_{0}, B$ and $T_{0}$ are $1.24 \times 10^{-5} \mathrm{~Pa} \mathrm{~s}, 25.1 \mathrm{~K}$ and $7.4 \mathrm{~K}$, respectively. The decrease in viscosity of $[\mathrm{BMP}]\left[\mathrm{Tf}_{2} \mathrm{~N}\right]$ at higher temperatures promotes the diffusion of $\mathrm{GeCl}_{4}$ which means that germanium can be electrodeposited at a high current density, but in order to reach these higher temperatures a pressurized cell must be used.

Fig. 5a shows the cyclic voltammograms of $0.5 \mathrm{M} \mathrm{GeCl}_{4}$ in $[\mathrm{BMP}]\left[\mathrm{Tf}_{2} \mathrm{~N}\right]$ at room temperature. The cyclic voltammograms were stopped at cathodic vertex potentials of $-1.0 \mathrm{~V},-1.2 \mathrm{~V}$, $-1.5 \mathrm{~V},-1.7 \mathrm{~V},-2.0 \mathrm{~V}$ and $-2.5 \mathrm{~V}$ to study the reactions happening at different potentials. There are two reduction peaks on the cathodic scan and three oxidation waves on the anodic scan. The second oxidation peak a2 correlated to the first reduction peak $\mathrm{r} 1$ at $-1.1 \mathrm{~V}$. The peak current density of a2 increased as more negative cathodic vertex potential was applied. The first reduction peak $\mathrm{r} 1$ is due to the reduction of $\mathrm{Ge}(\mathrm{IV})$ to $\mathrm{Ge}(\mathrm{II})$. This was further proven using potential scan experiment: a constant potential of $-1.0 \mathrm{~V}$ was applied until the charge density reached $2 \mathrm{C} \mathrm{dm}^{-2}$. Ge(II) ions were formed at the working electrode. Then the potential was scanned from $-1.0 \mathrm{~V}$ to $+1.5 \mathrm{~V}$ after waiting at open circuit potential for different times $(0 \mathrm{~s}, 10 \mathrm{~s}, 30 \mathrm{~s}$ and $300 \mathrm{~s})$. With longer waiting time, more $\mathrm{Ge}(\mathrm{II})$ ions diffused away from working electrode. The oxidation peak a2 which was due to the oxidation of $\mathrm{Ge}$ (II) to $\mathrm{Ge}$ (Iv) decreased as longer waiting times were applied (see ESI $\dagger$ ). When an even more negative cathodic vertex potential was applied, the second oxidation peak a2 decreased, less Ge(II) was in the solution because at the second reduction peak r2 $\mathrm{Ge}(\mathrm{II})$ was further reduced to $\mathrm{Ge}(0)$. The oxidation peak a3 corresponds to the oxidation of chloride ions to chlorine gas
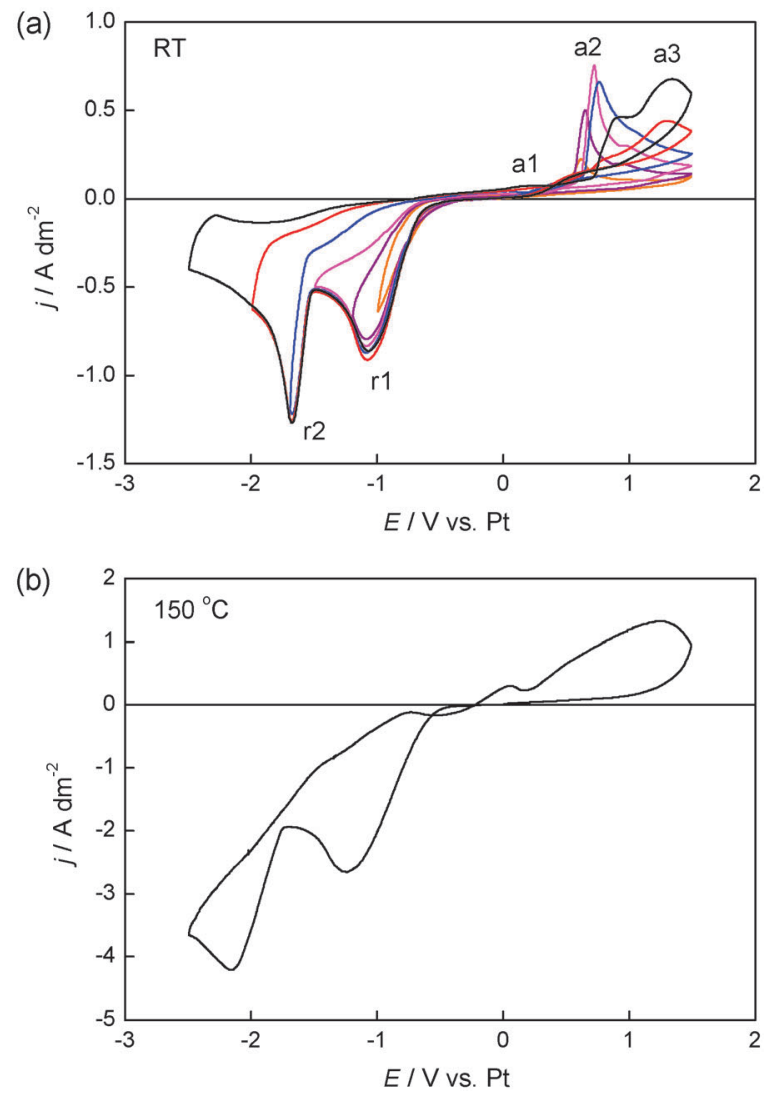

Fig. 5 Cyclic voltammograms of $0.5 \mathrm{M} \mathrm{GeCl}_{4}$ in $[\mathrm{BMP}]\left[\mathrm{Tf}_{2} \mathrm{~N}\right.$ ] at (a) room temperature and (b) $150{ }^{\circ} \mathrm{C}$. At room temperature, the cyclic voltammetry stopped at different cathodic vertex potentials of $-1.0 \mathrm{~V},-1.2 \mathrm{~V},-1.5 \mathrm{~V}$, $-2.0 \mathrm{~V}$ and $-2.5 \mathrm{~V}$. The working electrode was a platinum disk $(\phi=1 \mathrm{~mm})$ and the counter electrode was a $p$-type germanium wafer. The scan rate was $50 \mathrm{mV} \mathrm{s}^{-1}$.

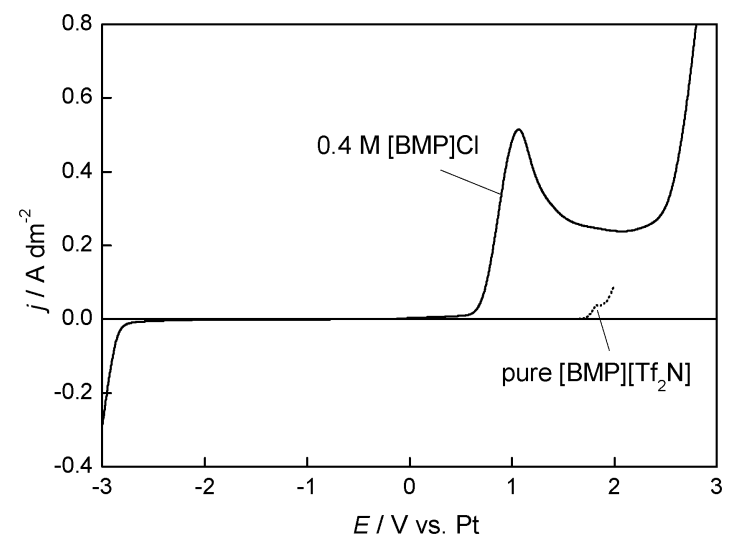

Fig. 6 Linear sweep voltammograms of $0.4 \mathrm{M}[\mathrm{BMP}] \mathrm{Cl}$ in $[\mathrm{BMP}]\left[\mathrm{Tf}_{2} \mathrm{~N}\right]$ (solid line) and pure $[\mathrm{BMP}]\left[\mathrm{Tf}_{2} \mathrm{~N}\right]$ (dotted line) at room temperature. The working electrode was a platinum disk $(\phi=1 \mathrm{~mm})$, the counter electrodes was a platinum coil. The scan rate was $50 \mathrm{mV} \mathrm{s}^{-1}$.

$\left(E_{\mathrm{Cl}_{2} / \mathrm{Cl}^{-}}^{0}=+1.36 \mathrm{~V}\right.$ vs. $\left.\mathrm{SHE}\right)$. Chloride ions are present in solution after reduction of $\mathrm{GeCl}_{4}$ to $\mathrm{Ge}(0)$. The oxidation potential of chloride ions was determined using a [BMP][ $\left.\mathrm{Tf}_{2} \mathrm{~N}\right]$ solution containing $0.4 \mathrm{M}$ [BMP]Cl. Fig. 6 shows the linear 
sweep voltammograms of $0.4 \mathrm{M}$ [BMP]Cl in [BMP][Tf $\left.{ }_{2} \mathrm{~N}\right]$. An oxidation peak could be observed at $+1.07 \mathrm{~V}$ which was due to the oxidation of chloride ions to chlorine gas. This peak is not present in pure [BMP]][Tf $\left.{ }_{2} \mathrm{~N}\right]$. The first oxidation peak a1 appeared only when the cathodic potential was scanned to the second reduction peak $\mathrm{r}$, indicating a1 was due to the stripping of $\mathrm{Ge}(0)$.

When the cell was immersed in the heating bath to $150{ }^{\circ} \mathrm{C}$ some gas bubbles were formed in the solution due to the high volatility of the $\mathrm{GeCl}_{4}$. The formation of gas bubbles stopped when the final temperature was reached. The cyclic voltammogram of $0.5 \mathrm{M} \mathrm{GeCl}_{4}$ in $[\mathrm{BMP}]\left[\mathrm{Tf}_{2} \mathrm{~N}\right]$ at $150{ }^{\circ} \mathrm{C}$ is quite similar to the cyclic voltammogram at room temperature (Fig. $5 \mathrm{~b}$ ). There are two reduction peaks on the cathodic scan. The first one at $-1.25 \mathrm{~V}$ is due to the reduction of $\mathrm{Ge}(\mathrm{Iv})$ to $\mathrm{Ge}(\mathrm{II})$, and the second reduction peak at $-2.1 \mathrm{~V}$ corresponds to the deposition of $\mathrm{Ge}(0)$. The peak current density is $-4.2 \mathrm{~A} \mathrm{dm}^{-2}$ compared to $-1.3 \mathrm{~A} \mathrm{dm}^{-2}$ at room temperature. The increase in the current density is due to the reduction of the viscosity at elevated temperatures. The decrease in viscosity leads to an increase in diffusion coefficient of $\mathrm{Ge}(\mathrm{Iv})$ ions in $[\mathrm{BMP}]\left[\mathrm{Tf}_{2} \mathrm{~N}\right]$. The diffusion coefficient of $\mathrm{Ge}(\mathrm{Iv})$ was calculated based on the following equations: ${ }^{35}$

$$
\begin{gathered}
j_{\mathrm{p}}=0.496 n \mathrm{~F} c\left(\frac{\alpha n_{\mathrm{a}} \mathrm{F} v D}{R T}\right)^{\frac{1}{2}} \\
E_{\mathrm{p}}-E_{\mathrm{p} / 2}=-\frac{47.7}{\alpha n_{\mathrm{a}}} \mathrm{mV}
\end{gathered}
$$

where $\mathrm{F}$ is the Faraday constant, $j_{\mathrm{p}}$ is peak current density $\left(\mathrm{A} \mathrm{m}^{-2}\right), n$ is the total number of electrons involved in the overall process, $n_{\mathrm{a}}$ is number of electrons involved in the rate determine step reaction, $\alpha$ is the charge transfer coefficient, $c$ is the concentration $\left(\mathrm{mol} \mathrm{m}^{-3}\right), v$ is the scan rate $\left(\mathrm{V} \mathrm{s}^{-1}\right), D$ is the diffusion coefficient $\left(\mathrm{m}^{2} \mathrm{~s}^{-1}\right), E_{\mathrm{p}}$ is the peak potential, and $E_{\mathrm{p} / 2}$ is the half peak potential. Cyclic voltammetry was performed in the potential range of the first reduction peak where Ge(Iv) is reduced to Ge(II) with different scan rates and the peak current density was plotted versus the square root of the scan rate $v$ (Fig. 7). The diffusion coefficient of $\mathrm{Ge}(\mathrm{Iv})$ in $[\mathrm{BMP}]\left[\mathrm{Tf}_{2} \mathrm{~N}\right]$ at room temperature $\left(22{ }^{\circ} \mathrm{C}\right)$ and $150{ }^{\circ} \mathrm{C}$ are $9.0 \times 10^{-12} \mathrm{~m}^{2} \mathrm{~s}^{-1}$ and $1.9 \times 10^{-10} \mathrm{~m}^{2} \mathrm{~s}^{-1}$, respectively, meaning that the diffusion coefficient at $150{ }^{\circ} \mathrm{C}$ is 22 times larger than that at room temperature. This is in close correspondence to the StokesEinstein relation:

$$
D=\frac{\mathrm{k}_{\mathrm{B}} T}{6 \pi \eta r}
$$

where $\mathrm{k}_{\mathrm{B}}$ is Boltzmann's constant, $\eta$ is the dynamic viscosity (Pa s), and $r$ is the hydrodynamic radius (m) of the diffusing species. The dynamic viscosity of the ionic liquid [BMP][ $\left.\mathrm{Tf}_{2} \mathrm{~N}\right]$ at room temperature is 18 times larger than that at $150{ }^{\circ} \mathrm{C}$ (see $\mathrm{ESI} \dagger$ ), and the diffusion coefficient is 26 times higher at $150{ }^{\circ} \mathrm{C}$ than that at room temperature.

The electrochemical behavior of [BMP][Tf $\left.{ }_{2} \mathrm{~N}\right]$ solution containing $\mathrm{GeCl}_{4}$ was further studied using electrochemical quartz crystal microbalance (EQCM). As shown in Fig. 8a, a cyclic
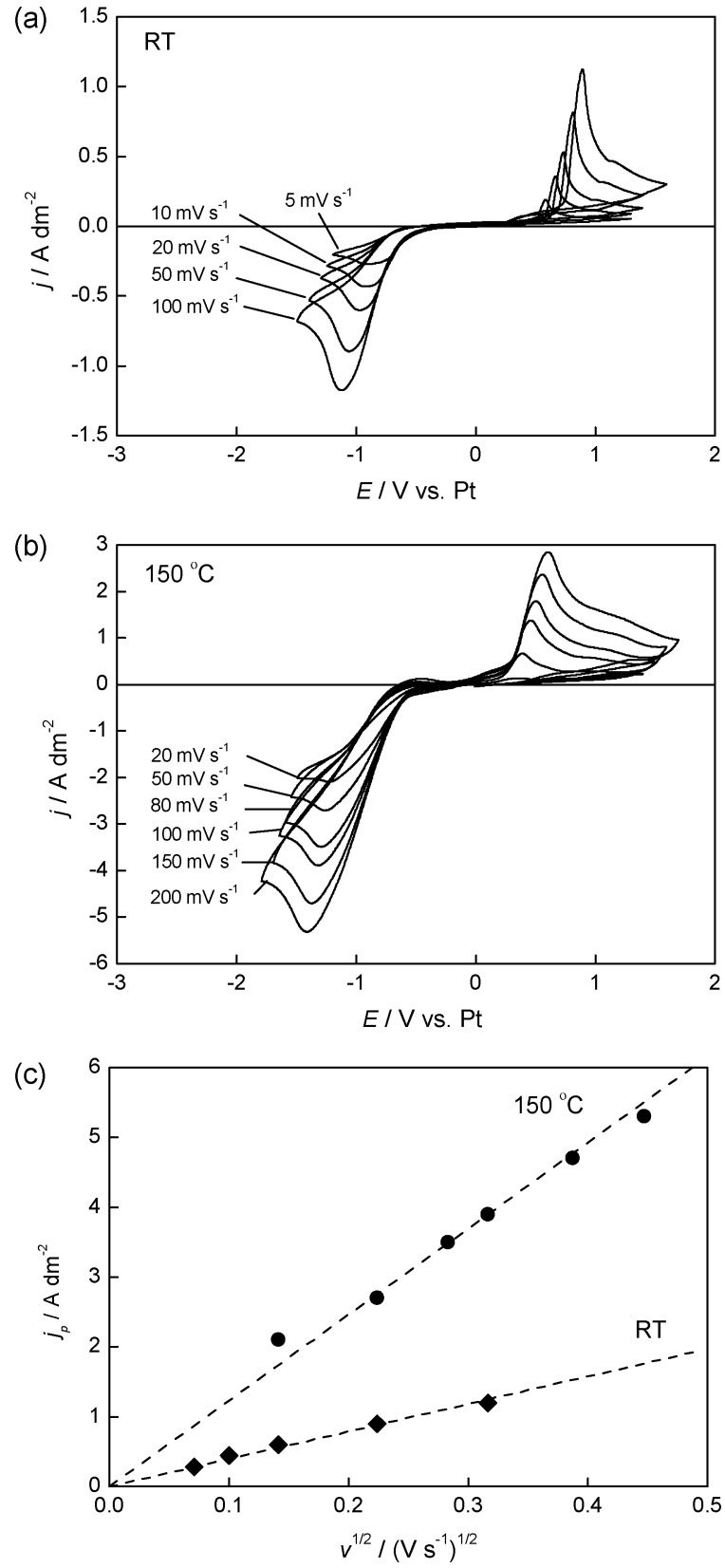

Fig. 7 Cyclic voltammograms of $0.5 \mathrm{M} \mathrm{GeCl}_{4}$ in [BMP] $\left[\mathrm{Tf}_{2} \mathrm{~N}\right]$ with different scan rates at (a) room temperature and (b) $150{ }^{\circ} \mathrm{C}$, and (c) the plot of current density versus the square root of the scan rate $v$.

voltammogram was recorded on a platinum-coated EQCM crystal working electrode, and the corresponding frequency change was simultaneously recorded by EQCM. Based on the frequency change, the mass change on the crystal was calculated from the Sauerbrey equation. The $\mathrm{m} / \mathrm{z}$ value was calculated at different potential ranges (Fig. 8b) and it varies for different reactions:

$$
\begin{array}{rl}
\mathrm{Ge}^{4+}+2 \mathrm{e}^{-} \rightarrow \mathrm{Ge}^{2+} & m / z=0 \\
\mathrm{Ge}^{4+}+4 \mathrm{e}^{-} \rightarrow \mathrm{Ge}^{0} & m / z=18.2 \mathrm{~g} \mathrm{~mol}^{-1} \\
\mathrm{Ge}^{2+}+2 \mathrm{e}^{-} \rightarrow \mathrm{Ge}^{0} & m / z=36.3 \mathrm{~g} \mathrm{~mol}^{-1}
\end{array}
$$



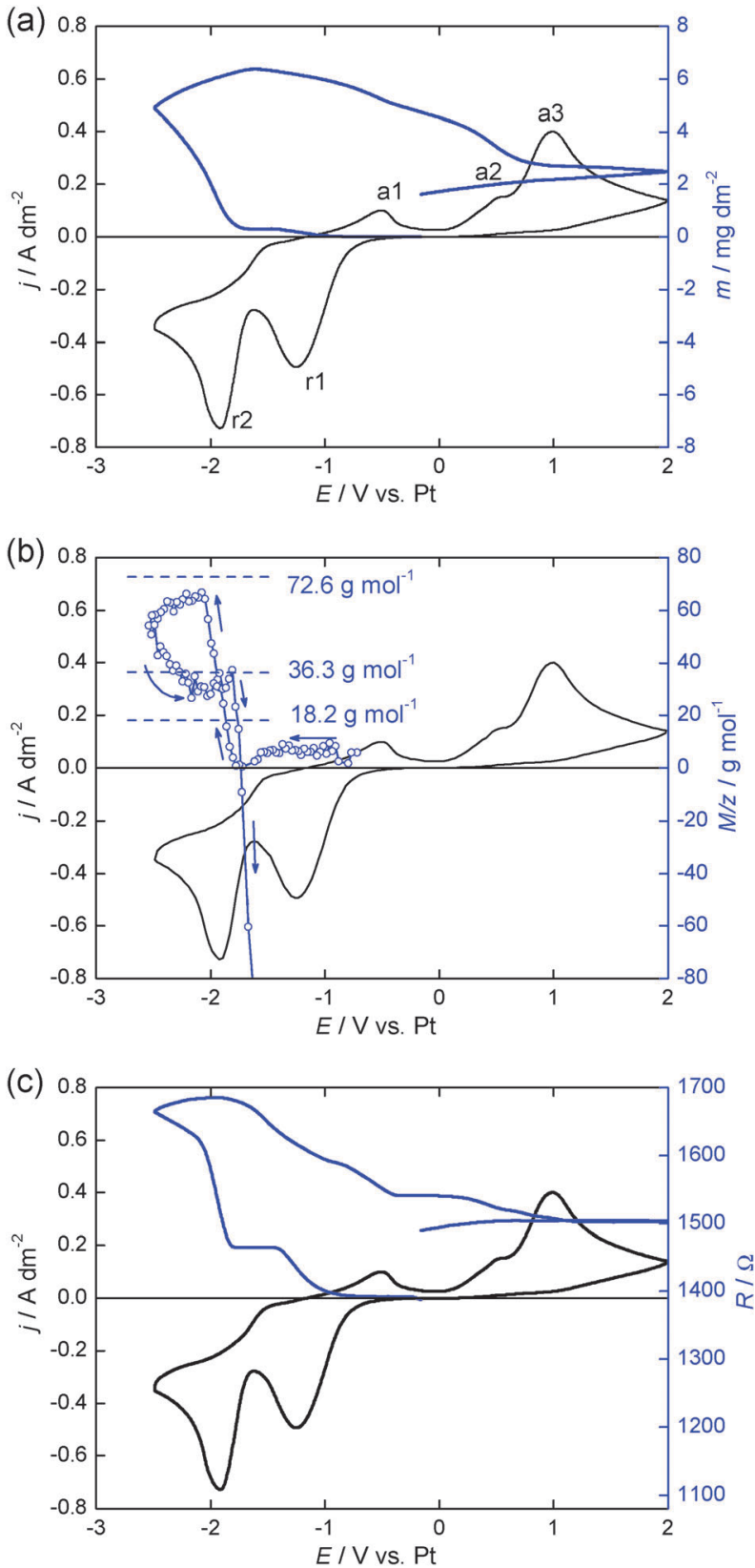

Fig. 8 Cyclic voltammograms and corresponding (a) mass change, (b) $\mathrm{m} / \mathrm{z}$ value change, and (c) resonance resistance change in a $[\mathrm{BMP}]\left[\mathrm{Tf}_{2} \mathrm{~N}\right]$ solution containing $0.1 \mathrm{M} \mathrm{GeCl}_{4}$ at $50{ }^{\circ} \mathrm{C}$. The counter electrode was a platinum coil and the scan rate was $50 \mathrm{mV} \mathrm{s}^{-1}$.

The first reduction peak was assigned to the reduction of $\mathrm{Ge}(\mathrm{IV})$ to $\mathrm{Ge}(\mathrm{II})$. Thus, no mass increase was expected at this potential range. However a small mass increase was observed and the increase of mass stopped when reached a certain value. This is consistent with the observation of Endres and co-workers using a scanning tunneling microscope (STM). ${ }^{16}$ They found the growth of germanium islands at the beginning of the first reduction peak and the formation of a coherent, closed germanium layer when the potential was scanned to slightly more negative values than the first reduction peak. This layer hardly changed until the beginning of the second reduction peak. ${ }^{16}$
Xie et al. explained that two electrochemical reactions take place at the first reduction peak: the reduction of $\mathrm{Ge}(\mathrm{Iv})$ to Ge(II) and the underpotential deposition (UPD) of germanium. ${ }^{36}$ At the second reduction wave, the potential is negative enough for reaction (9) to take place. In the beginning, the reduction rate of $\mathrm{Ge}(\mathrm{II})$ to $\mathrm{Ge}(0)$ was not fast enough to catch up with the rate of formation of Ge(II) so the $m / z$ value increased from 0 to $65 \mathrm{~g} \mathrm{~mol}^{-1}$ as the potential scanned to more negative values. Based on eqn (8) and (9), the $m / z$ value should not exceed $36.3 \mathrm{~g} \mathrm{~mol}^{-1}$. The morphology of the germanium film led to this abnormal increase in $\mathrm{m} / \mathrm{z}$ value. Endres and co-workers found germanium nanoclusters forming during cathodic scan from ionic liquid 1-butyl3-methylimidazolium hexafluorophosphate containing $\mathrm{GeCl}_{4} \cdot{ }^{16}$ The roughness of the germanium surface leads to the increase in frequency change which can be explained by several possible mechanisms. ${ }^{37}$ This also can be reflected from the ratio between resonance frequency change $(\Delta f)$ and resistance change $(\Delta R)$ of the crystal: ${ }^{38}$

$$
S=\frac{\Delta f}{\Delta R}=\frac{32 f^{3} A_{\mathrm{r}}\left(\rho_{\mathrm{q}} e_{\mathrm{q}}\right)^{2}}{2 \pi\left(\rho_{\mathrm{q}} \mu_{\mathrm{q}}\right)^{\frac{3}{2}}}
$$

where $f$ is the resonance frequency of a loaded crystal $(\mathrm{Hz}), A_{\mathrm{r}}$ is the active area of the 1 -inch crystal $\left(3.419 \times 10^{-5} \mathrm{~m}^{2}\right), \rho_{\mathrm{q}}$ is the density of quartz $\left(2.648 \times 10^{3} \mathrm{~kg} \mathrm{~m}^{3}\right), e_{\mathrm{q}}$ is the piezoelectric constant for an AT cut quartz $\left(0.095 \mathrm{~kg} \mathrm{~s}^{2} \mathrm{~V}^{-1}\right)$, and $\mu_{\mathrm{q}}$ is the shear modulus of quartz $\left(2.947 \times 10^{10} \mathrm{~Pa}\right)$. The $S$ is calculated from the equation and it should be around 1.97 if the surface is absolute smooth. If the EQCM working surface is absolutely smooth, the $S$ value is a constant. It increases proportional to the degree of surface roughness. ${ }^{39}$ Fig. 8c shows the resonance resistance change. The $S$ value at $-1.6 \mathrm{~V}$ was 2.5 and it increased to 11.5 at $-2.5 \mathrm{~V}$ illustrating the fact that the electrodeposited germanium was rough.

On the cathodic back scan, a mass decrease was observed from $-1.6 \mathrm{~V}$ on, due to the chemical dissolution of germanium deposit via the comproportionation reaction:

$$
\mathrm{Ge}^{4+}+\mathrm{Ge}^{0} \rightleftharpoons 2 \mathrm{Ge}^{2+} .
$$

In order to exclude the effect of the ionic liquid on the dissolution of germanium film, two germanium films $\left(8.9 \mathrm{C} \mathrm{dm}^{-2}\right)$ were electrodeposited from $0.1 \mathrm{M} \mathrm{GeCl}_{4}$ in $[\mathrm{BMP}]\left[\mathrm{Tf}_{2} \mathrm{~N}\right]$ at $-2.0 \mathrm{~V}$ at room temperature. Then they were immersed into two different solutions: (a) dried ionic liquid [BMP] $\left[\mathrm{Tf}_{2} \mathrm{~N}\right]$, and (b) fresh prepared $0.1 \mathrm{M} \mathrm{GeCl}_{4}$ in $[\mathrm{BMP}]\left[\mathrm{Tf}_{2} \mathrm{~N}\right]$. After 12 hours, the germanium films in solution (b) was completely dissolved while the germanium film in the pure $[\mathrm{BMP}]\left[\mathrm{Tf}_{2} \mathrm{~N}\right]$ stayed intact even after 7 days. This suggests that the pure ionic liquid [BMP] $\left.\mathrm{Tf}_{2} \mathrm{~N}\right]$ does not attack the germanium film and germanium film dissolved only in the solution containing $\mathrm{GeCl}_{4}$. The mass decrease during the cathodic scan was due to the comproportionation reaction (11). On the anodic scan, due to the chemical and electrochemical dissolution of germanium, the mass decreased. At potentials more positive than $+0.8 \mathrm{~V}$, a large anodic peak was observed, however there was almost no mass loss in that potential range. This suggests that the main oxidation peak 


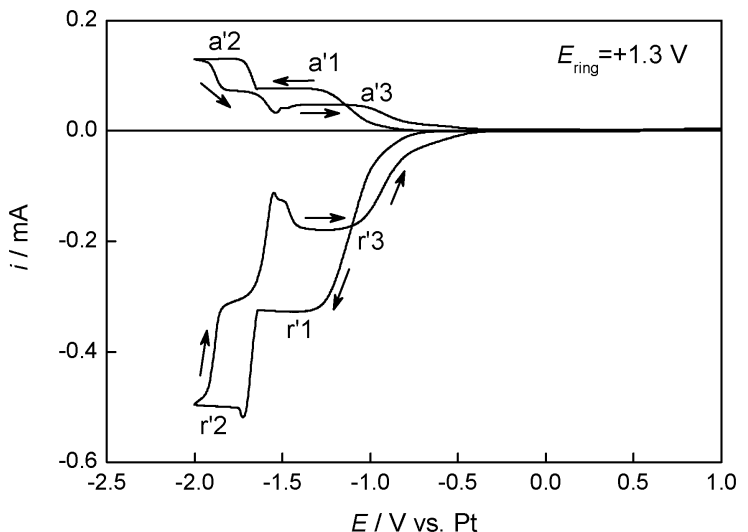

Fig. 9 Rotating ring-disk electrode result from $0.5 \mathrm{M} \mathrm{GeCl}_{4}$ in $[\mathrm{BMP}]\left[\mathrm{Tf}_{2} \mathrm{~N}\right]$ at room temperature: a cyclic voltammogram was applied on the disk at a scan rate of $2 \mathrm{mV} \mathrm{s}^{-1}$ and a ring potential of $+1.3 \mathrm{~V}$ was applied. The rotation speed was $500 \mathrm{rpm}$.

does not correspond to the dissolution of germanium. This oxidation peak corresponded to the oxidation of chloride ions.

The rotating-ring disk electrode experiments provide clear evidence of the formation of Ge(II) at the first reduction peak. A cyclic voltammogram was performed on the disk and a constant potential of $+1.3 \mathrm{~V}$ was applied on the ring (Fig. 9). At the first reduction plateau $\mathrm{r}^{\prime} 1, \mathrm{Ge}(\mathrm{Iv})$ was reduced to $\mathrm{Ge}(\mathrm{II})$ and then the Ge(II) convected to the ring and this Ge(II) was oxidized back to $\mathrm{Ge}(\mathrm{IV})$ on the ring. Thus, a corresponding current a' 1 was observed on the ring. At the second reduction wave $\mathrm{r}^{\prime} 2, \mathrm{Ge}(\mathrm{II})$ was reduced to $\mathrm{Ge}(0)$, and no oxidation current is expected on the ring. However, an anodic current $a^{\prime} 2$ was observed. This is because chloride ions are liberated from the germanium complex when $\mathrm{Ge}(\mathrm{II})$ is reduced to $\mathrm{Ge}(0)$. The chloride ions were convected to the ring and were oxidized to chlorine gas. The formation of germanium on the disk led to the passivation of the electrode, and as a result, the disk current decreased. At the third reduction plateau $\mathrm{r}^{\prime} 3$, Ge(Iv) was reduced to $\mathrm{Ge}(\mathrm{II})$ which is the same reaction on $\mathrm{r}^{\prime} 1$, but the

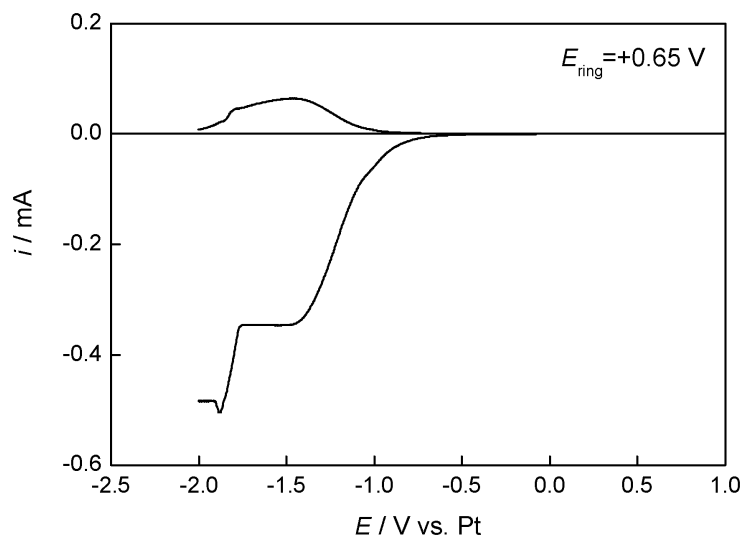

Fig. 10 Rotating ring-disk electrode result from $0.5 \mathrm{M} \mathrm{GeCl}_{4}$ in [BMP][Tf $f_{2} \mathrm{~N}$ ] at room temperature: a cyclic voltammogram was applied on the disk at a scan rate of $2 \mathrm{mV} \mathrm{s}^{-1}$ and a ring potential of $+0.65 \mathrm{~V}$ was applied. The rotation speed was $500 \mathrm{rpm}$.

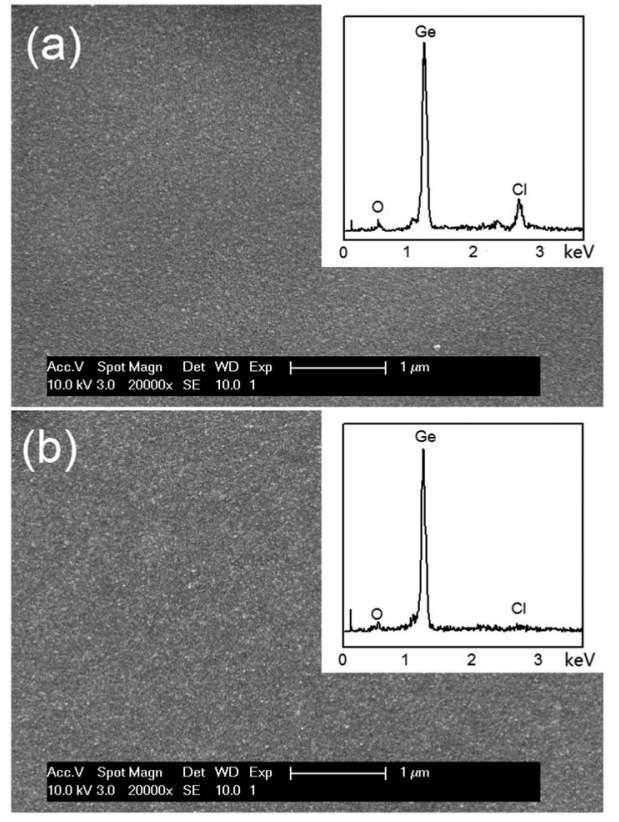

Fig. 11 SEM images of electrodeposited germanium films. The germanium films were electrodeposited from $[\mathrm{BMP}]\left[\mathrm{Tf}_{2} \mathrm{~N}\right]$ solution containing $0.5 \mathrm{M} \mathrm{GeCl}_{4}$ at different potentials and temperatures: (a) $-1.2 \mathrm{~V}$ at $150{ }^{\circ} \mathrm{C}$ and (b) $-0.9 \mathrm{~V}$ at $180{ }^{\circ} \mathrm{C}$ for one hour. The counter electrode was a p-type germanium wafer. The solution was stirred by a magnetic stir bar.

current is much lower. In order to prevent the oxidation of chloride ions on the ring, the ring potential was changed to $+0.65 \mathrm{~V}$ where $\mathrm{Ge}(\mathrm{II})$ can be oxidized to $\mathrm{Ge}(\mathrm{IV})$ but not positive enough for oxidizing chloride ions. The result is shown in Fig. 10. At the first reduction peak, a ring current was observed. The ring current was lower than the limiting current due to the applied potential was not positive enough. At the second reduction peak, the ring current dropped to zero.

Germanium films were electrodeposited from [BMP] $\left[\mathrm{Tf}_{2} \mathrm{~N}\right]$ solutions at elevated temperatures in order to investigate their morphologies. Fig. 11a shows the SEM pictures of the germanium film electrodeposited at $150{ }^{\circ} \mathrm{C}$. The film was electrodeposited at $-1.2 \mathrm{~V}$ with an average current density of $-0.35 \mathrm{~A} \mathrm{dm}^{-2}$, and the theoretical thickness calculated from the charge was $4.8 \mu \mathrm{m}$. The germanium film had a very flat and uniform morphology, but there were a few cracks on the macroscale (see ESI $\dagger$ ). In the EDX spectrum, a very small oxygen peak was observed which was due to the oxidation of germanium in the air. A chlorine peak was also found in the EDX. Endres and co-workers attributed the presence of chlorine to $\mathrm{GeCl}_{3}$ termination of the deposit-electrolyte interface. ${ }^{18}$ Fig. 11c shows SEM picture of the germanium film electrodeposited at $-0.9 \mathrm{~V}$ at $180{ }^{\circ} \mathrm{C}$. The EDX spectrum for this film shows a very small oxygen peak and barely a chlorine peak. The film deposited at $180{ }^{\circ} \mathrm{C}$ had a grey but shiny metallic appearance, and no cracks were found in the film (see ESI $\dagger$ ). The average current density was $-0.46 \mathrm{~A} \mathrm{dm}^{-2}$ and the theoretical thickness was $5.8 \mu \mathrm{m}$. Increasing the deposition temperature, not only increased the deposition rate, but also prevented the formation of cracks in the dense films. Dissolution of the p-type germanium anode was observed during electrodeposition. The surface of the 


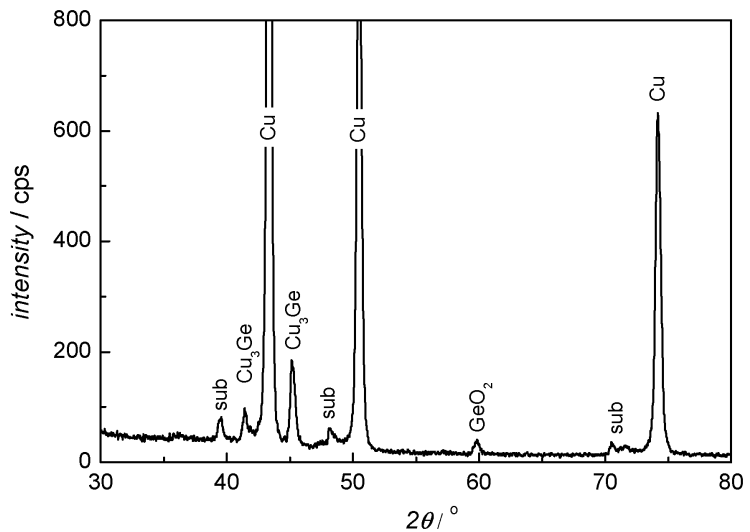

Fig. 12 XRD pattern of the germanium film deposited on copper substrate from $0.5 \mathrm{M} \mathrm{GeCl}_{4}$ in $[B M P]\left[\mathrm{Tf}_{2} \mathrm{~N}\right]$ at $150{ }^{\circ} \mathrm{C}$. The deposition potential was $-1.5 \mathrm{~V}$ vs. Pt. The counter electrode was a $p$-type germanium wafer. The peaks labeled as "sub" came from the the XRD pattern originated from the sample holder.

germanium wafer became rough. The color of the solution did not change after electrodeposition.

The electrodeposited germanium film was removed from the substrate using resin and analyzed by XRD. No diffraction peaks were observed for the germanium film which indicates that the electrodeposited germanium on platinum was amorphous. Germanium was also electrodeposited on a copper substrate, however, XRD diffraction peaks for $\mathrm{Cu}_{3} \mathrm{Ge}$ alloy were observed. This suggests that electrodeposited germanium formed an alloy with the copper substrate (Fig. 12).

Maldonado and co-workers were the first to report the epitaxial electrodeposition of germanium nanowires from an aqueous solution, and their work required the formation of gallium nanodroplets. ${ }^{40}$ In principle, at elevated temperature, due to the increase of the adatom mobility epitaxial growth of germanium on germanium substrate can be achieved if the surface of the germanium substrate is free of contaminations like oxides, grease, etc. The n-type germanium(100) substrates were rinsed with deionized water before using to remove most of the native oxides on the surface. Also, thanks to the comproportionation reaction (11), germanium substrates should be "self-cleaned" in the $[\mathrm{BMP}]\left[\mathrm{Tf}_{2} \mathrm{~N}\right]$ solution containing $\mathrm{GeCl}_{4}$. This was supposed to prevent the existence of a native oxide layer between the germanium wafer and the electrolyte. However, the transmission electron microscopy (TEM) picture of the cross-section of the germanium layer deposited on germanium substrate shows the interface was not clean (Fig. 13). The electron diffraction patterns indicates that the deposited germanium film was amorphous whereas the substrate was single crystalline. In order to eliminate oxygen from the germanium substrates, a positive potential of $+1.0 \mathrm{~V}$ was applied for different times ( $3 \mathrm{~s}, 10 \mathrm{~s}, 15 \mathrm{~s}$ and $20 \mathrm{~s})$ before deposition to dissolve top layer of germanium. The films were characterized by the electron backscatter diffraction (EBSD). Kikuchi pattern of germanium was always found on the substrates, but the electrodeposited films did not give rise to any Kikuchi diffraction patterns. Epitaxial growth of germanium was not successful

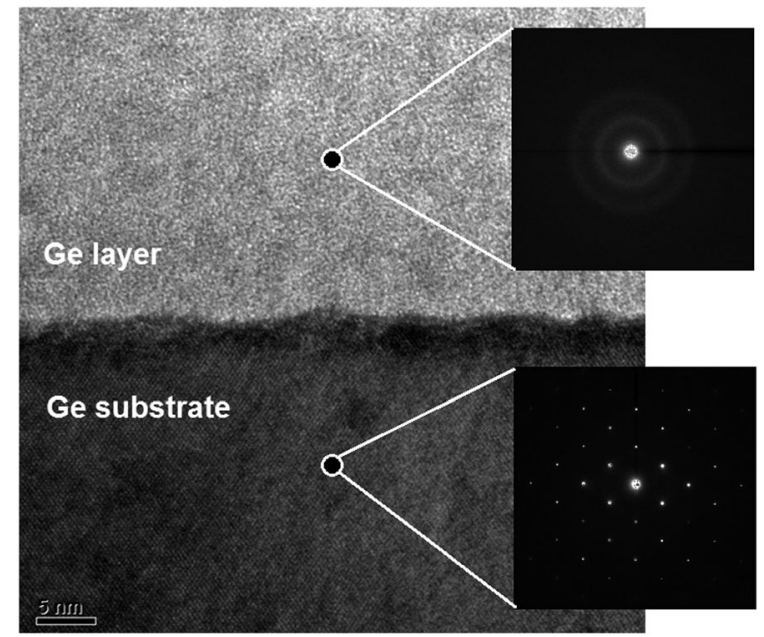

Fig. 13 TEM image and electron diffraction patterns of the cross-section of the germanium film electrodeposited on an n-type germanium substrate. The film was deposited from $0.5 \mathrm{M} \mathrm{GeCl}_{4}$ in $[\mathrm{BMP}]\left[\mathrm{Tf}_{2} \mathrm{~N}\right]$ at $180{ }^{\circ} \mathrm{C}$ at $-0.9 \mathrm{~V} v$ s. Pt. The solution was stirred by a magnetic stir bar.

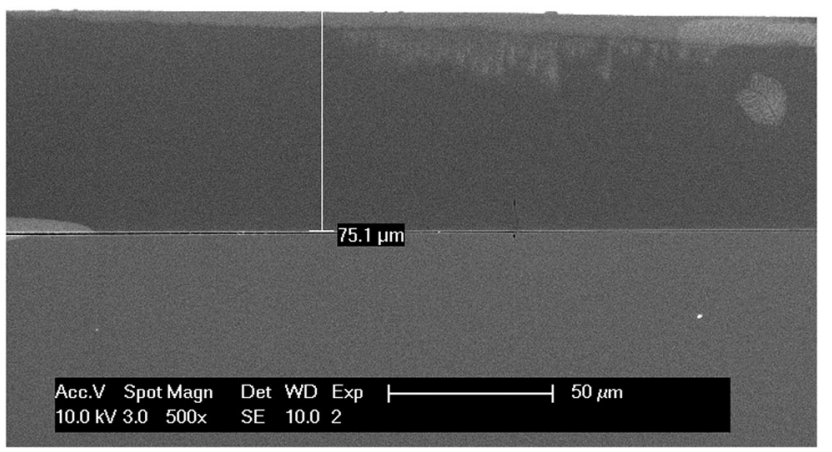

Fig. 14 SEM image of the cross-section of the germanium film electrodeposited on an n-type germanium substrate. The film was deposited from $0.5 \mathrm{M} \mathrm{GeCl}_{4}$ in $[\mathrm{BMP}]\left[\mathrm{Tf}_{2} \mathrm{~N}\right]$ at $180{ }^{\circ} \mathrm{C}$ at $-0.9 \mathrm{~V}$ vs. Pt for $12.4 \mathrm{~h}$. The solution was stirred by a magnetic stir bar.

even with the pre-dissolution of germanium wafer before deposition.

Fig. 14 shows the SEM image of the cross-section of a thick germanium film ( $75 \mu \mathrm{m}$ thick) electrodeposited on germanium. The film was very dense but partially delaminated from the substrate. The deposition rate reached about $6.0 \mu \mathrm{m} \mathrm{h}^{-1}$. The energy-dispersive X-ray spectroscopy (EDS) illustrates the presence of chlorine as well as oxygen and carbon impurities. The purity of the germanium film was further analyzed using Auger electron spectroscopy (AES) (Fig. 15). Without etching, carbon and oxygen were detected on the surface of the electrodeposited germanium and the germanium peaks were almost invisible which means the germanium surface was covered with a contamination layer. After the first etching cycle, the oxygen and carbon peaks reduced and germanium peaks can be clearly observed. However a small peak at about $184 \mathrm{eV}$ appeared which is associated with chlorine. Carbon and oxygen peaks were vanished after four etching cycles, but the chlorine peak was still there. The concentration of chlorine in germanium is 


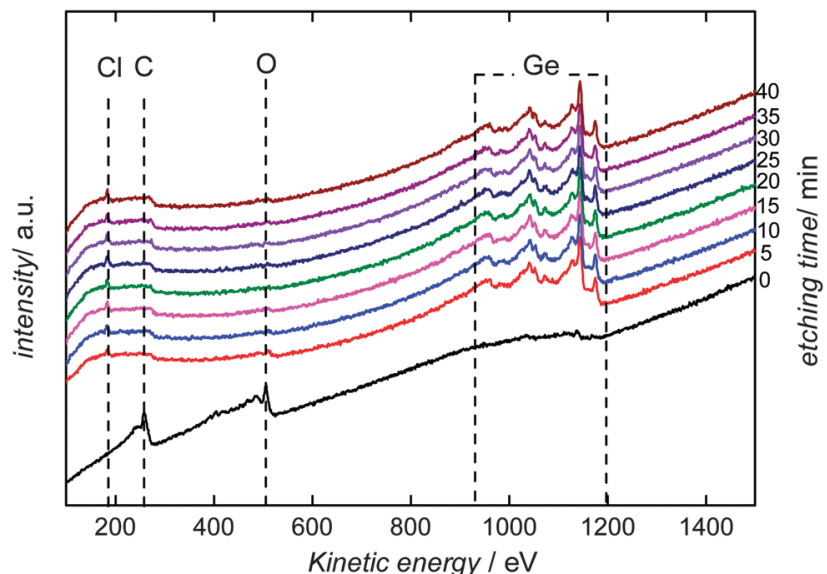

Fig. 15 Auger electron spectra of the germanium film deposited on an ntype germanium substrate from $0.5 \mathrm{M} \mathrm{GeCl}_{4}$ in $[\mathrm{BMP}]\left[\mathrm{Tf}_{2} \mathrm{~N}\right]$ at $180{ }^{\circ} \mathrm{C}$ at -0.9 V vs. Pt.

difficult to quantify due to the low signal intensity and thus a low signal-to-noise ratio, therefore no proper peak fitting could be obtained. The presence of those impurities in the film can be another reason for the absence of epitaxial growth.

\section{Conclusions}

The electrodeposition of germanium from $\mathrm{GeCl}_{4}$ in the ionic liquid 1-butyl-1-methylpyrrolidinium bis(trifluoromethylsulfonyl)imide has been studied in a pressure cell at elevated temperatures up to $180{ }^{\circ} \mathrm{C}$. The viscosity of the solution decreased from $69.7 \times$ $10^{-3} \mathrm{~Pa} \mathrm{~s}$ at room temperature to $3.8 \times 10^{-3} \mathrm{~Pa} \mathrm{~s}$ at $150{ }^{\circ} \mathrm{C}$. The diffusion coefficient of germanium increased to $1.9 \times 10^{-10} \mathrm{~m}^{2} \mathrm{~s}^{-1}$ at $150{ }^{\circ} \mathrm{C}$. High deposition rates up to $6.0 \mu \mathrm{m} \mathrm{h}^{-1}$ could be obtained. The germanium films obtained at elevated temperatures had a grey or silver shiny metallic color. The germanium deposited on both platinum and n-type germanium substrates was amorphous. Orange germanium films were also obtained from 1-butyl-1methylpyrrolidinium dicyanamide containing $\left[\mathrm{GeCl}_{4}(\mathrm{BuIm})_{2}\right]$ at $120{ }^{\circ} \mathrm{C}$. The deposition rate reached $2.0 \mu \mathrm{m} \mathrm{h}^{-1}$. Due to the fast polymerization of dicyanamide anions at elevated temperatures, germanium films could not be obtained in this ionic liquid at temperatures higher than $140{ }^{\circ} \mathrm{C}$.

\section{Acknowledgements}

The authors acknowledge financial support from the IWT (SBO project "Material processing in ionic liquids", MAPIL) and the FWO-Flanders (Research community "Ionic liquids", and research project G0B9613N). Support by IoLiTec (Heilbronn, Germany) is gratefully acknowledged. The authors thank Umicore (Olen, Belgium) for a generous gift of germanium(Iv) chloride. The authors also acknowledge Prof. Philippe Vereecken for his help with the rotating ring-disk electrode experiment, and Prof. Marc Heyns for providing the germanium wafers and Prof. Bert Verlinden, Tom Van der Donck, Dr Xiebin Wang, I. R. Ling Qin and I. R. Chen Li for their help with EBSD, and
Prof. Jean-Pierre Locquet and Dr Bastiaan Opperdoes for the AES measurement, and MA-tek for their help with TEM measurement.

\section{References}

1 N. Chandrasekharan and S. C. Sevov, J. Electrochem. Soc., 2010, 157, C140-C145.

2 J. Gu, E. Fahrenkrug and S. Maldonado, J. Am. Chem. Soc., 2013, 135, 1684-1687.

3 J. Ke, P. N. Bartlett, D. Cook, T. L. Easun, M. W. George, W. Levason, G. Reid, D. Smith, W. Su and W. Zhang, Phys. Chem. Chem. Phys., 2012, 14, 1517-1528.

4 X. Meng, R. Al-Salman, J. Zhao, N. Borissenko, Y. Li and F. Endres, Angew. Chem., Int. Ed., 2009, 48, 2703-2707.

5 X. Liang, Y.-G. Kim, D. K. Gebergziabiher and J. L. Stickney, Langmuir, 2010, 26, 2877-2884.

6 M. J. Jawad, M. R. Hashim, N. K. Ali, E. P. Córcoles and M. E. Sharifabad, J. Electrochem. Soc., 2012, 159, D124-D128.

7 A. I. Carim, S. M. Collins, J. M. Foley and S. Maldonado, J. Am. Chem. Soc., 2011, 133, 13292-13295.

8 C. G. Fink and V. M. Dokras, J. Electrochem. Soc., 1949, 95, 80-97.

9 G. Szekely, J. Electrochem. Soc., 1951, 98, 318-324.

10 M. Saitou, K. Sakae and W. Oshikawa, Surf. Coat. Technol., 2002, 162, 101-105.

$11 \mathrm{H}$. Ohno, Electrochemical aspects of ionic liquids, John Wiley \& Sons, Inc., Hoboken, New Jersey, 2005.

12 M. Armand, F. Endres, D. R. MacFarlane, H. Ohno and B. Scrosati, Nat. Mater., 2009, 8, 621-629.

13 N. V. Plechkova and K. R. Seddon, Chem. Soc. Rev., 2008, 37, 123-150.

14 F. Endres, D. MacFarlane and A. Abbott, Electrodeposition from ionic liquids, Wiley-VCH, Weinheim, 2008.

15 F. Endres, Phys. Chem. Chem. Phys., 2001, 3, 3165-3174.

16 F. Endres and S. Zein El Abedin, Phys. Chem. Chem. Phys., 2002, 4, 1649-1657.

17 F. Endres and S. Zein El Abedin, Phys. Chem. Chem. Phys., 2002, 4, 1640-1648.

18 F. Endres, Electrochem. Solid-State Lett., 2002, 5, C38-C40.

19 I. Mukhopadhyay and W. Freyland, Chem. Phys. Lett., 2003, 377, 223-228.

20 F. Martineau, K. Namur, J. Mallet, F. Delavoie, F. Endres, M. Troyon and M. Molinari, Mater. Sci. Eng., 2009, 6, 012012.

21 R. Al-Salman, S. Zein El Abedin and F. Endres, Phys. Chem. Chem. Phys., 2008, 10, 4650-4657.

22 W. Xin, J. Zhao, D. Ge, Y. Ding, Y. Li and F. Endres, Phys. Chem. Chem. Phys., 2013, 48, 2421-2426.

23 R. W. Chia, C. C. Wang and J. J. Lee, J. Magn. Magn. Mater., 2000, 209, 45-49.

24 M. Wu, N. R. Brooks, S. Schaltin, K. Binnemans and J. Fransaer, Phys. Chem. Chem. Phys., 2013, 15, 4955-4964.

25 R. E. Hummel, Electronic Properties of Materials, Springer Verlag, Berlin, 2011.

26 C. Gabrielli, M. Keddam and R. Torresi, J. Electrochem. Soc., 1991, 138, 2657-2660. 
27 N. R. Brooks, S. Schaltin, K. Van Hecke, L. Van Meervelt, J. Fransaer and K. Binnemans, Dalton Trans., 2012, 41, 6902-6905.

28 S. Schaltin, L. D’Urzo, Q. Zhao, A. Vantomme, H. Plank, G. Kothleitner, C. Gspan, K. Binnemans and J. Fransaer, Phys. Chem. Chem. Phys., 2012, 14, 13624-13629.

29 T. Romann, O. Oll, P. Pikma, K. Kirsimäe and E. Lust, J. Power Sources, 2015, 280, 606-611.

30 O.-H. Kim, Y.-H. Cho, D. Y. Chung, M. J. Kim, J. M. Yoo, J. E. Park, H. Choe and Y.-E. Sung, Sci. Rep., 2015, 5, 8376.

31 A. W. Laubengayer and D. L. Tabern, J. Phys. Chem., 1926, 30, 1047-1048.

32 M. Vranes, S. Dozic, V. Djeric and S. Gadzuric, J. Chem. Eng. Data, 2012, 57, 1072-1077.

33 M. Geppert-Rybczynska, A. Knorr, J. K. Lehmann and A. Heintz, J. Chem. Eng. Data, 2012, 57, 1923-1927.
34 J. Russell, D. Giordano and D. Dingwell, Am. Mineral., 2003, 88, 1390-1394.

35 M. Noel and K. I. Vasu, Cyclic Voltammetry and the Frontiers of Electrochemistry, Oxford \& IBH Publishing Company, 1990.

36 X.-F. Xie, J.-W. Yan, J.-H. Liang, J.-J. Li, M. Zhang and B.-W. Mao, J. Electrochem., 2014, 20, 12-16.

37 L. Daikhin, E. Gileadi, G. Katz, V. Tsionsky, M. Urbakh and D. Zagidulin, Anal. Chem., 2002, 74, 554-561.

38 MAXTEK, INC. Operation and service manual-RQCM research quartz Crystal microbalance.

39 N.-J. Cho, J. N. D’Amour, J. Stalgren, W. Knoll, K. Kanazawa and C. W. Frank, J. Colloid Interface Sci., 2007, 315, 248-254.

40 E. Fahrenkrug, J. Gu, S. Jeon, P. A. Veneman, R. S. Goldman and S. Maldonado, Nano Lett., 2014, 14, 847-852. 